\title{
ILCEA
}

Revue de l'Institut des langues et cultures

d'Europe, Amérique, Afrique, Asie et Australie

$25 \mid 2016$

De la bibliothèque intérieure à la bibliothèque collective : livres et lectures en Espagne (XVI ${ }^{e}-X X I^{e}$ siècles)

\section{La biblioteca en construcción del abad de Rute}

Piecing Together the Abbot of Rute's Library

La bibliothèque en construction de l'abbé de Rute

\section{Muriel Elvira}

\section{OpenEdition}

\section{Journals}

\section{Edición electrónica}

URL: http://journals.openedition.org/ilcea/3699

DOI: 10.4000/ilcea.3699

ISSN: 2101-0609

Editor

UGA Éditions/Université Grenoble Alpes

Edición impresa

ISBN: 978-2-84310-322-3

ISSN: $1639-6073$

\section{Referencia electrónica}

Muriel Elvira, « La biblioteca en construcción del abad de Rute », ILCEA [En línea], 25 | 2016, Publicado el 31 enero 2016, consultado el 01 mayo 2019. URL : http://journals.openedition.org/ilcea/3699 ; DOI : 10.4000/ilcea.3699

Este documento fue generado automáticamente el 1 mayo 2019.

(c) ILCEA 


\title{
La biblioteca en construcción del abad de Rute
}

\author{
Piecing Together the Abbot of Rute's Library \\ La bibliothèque en construction de l'abbé de Rute
}

Muriel Elvira

1 Digámoslo de entrada ${ }^{1}$ : no disponemos de ningún inventario de la biblioteca personal de Francisco Fernández de Córdoba, abad de Rute y racionero de la iglesia de Córdoba. Todo indica que era abundante y que abarcaba una gran variedad de temas, humanos y divinos, pues desde Rute, donde residía al final de su vida, contestaba a las preguntas de erudición de sus corresponsales con el solo instrumento de su biblioteca personal. Además los fragmentos hasta ahora publicados de su correspondencia con Díaz de Rivas, editados por Dámaso Alonso (1982a), nos lo revelan, en el otoño de su vida, todavía ávido de comprar libros, nuevos o antiguos, para completarla.

2 A falta de este inventario, tenemos sus obras que atestiguan lecturas abundantes y variadas, siempre de primera mano. El abad de Rute es hoy conocido de los hispanistas por su participación en la polémica gongorina, para la cual compuso tres textos de diversa extensión en defensa de la poesía de Góngora: el Parecer de 1614 (Elvira, 2015), la corta Apología por una décima probablemente de finales de 1615 o principios de 1616 (Gates, 1951), y el largo y denso Examen del Antídoto de 1617 (Artigas, 1925). Sin embargo en su tiempo se dio a conocer principalmente por otros trabajos considerados por él y sus coetáneos como más serios: una miscelánea de erudición en latín titulada Didascalia multiplex, terminada por los años de 1611-1612 aunque publicada algunos años después (Fernández de Córdoba, 1615); un tratado sobre la vida de San Matías, hoy perdido ${ }^{2}$ y, sobre todo, la Historia de la Casa de Córdoba, que dejó inédita a su muerte³, en la cual hace gala de sus talentos de historiador y genealogista, pues enumera en ella, sin excepción, a todos los miembros que la compusieron, incluyéndose a sí mismo, y narrando de forma extendida las hazañas de sus miembros más destacados (Fernández de Córdoba, 1954-1972). 
3 Todas estas obras revelan la extensión de su curiosidad intelectual y una variedad de temas impresionante: poesía, teatro, retórica, derecho, filosofía, teología, historia (moderna y antigua), arqueología, genealogía, epigrafía, numismática, geografía. Suponen además lecturas sólidas, nada apresuradas, de una cantidad ingente de libros cotejados entre sí. En efecto, la erudición del abad de Rute se fundamenta en un método enciclopédico de acopio de referencias y citas sobre un tema dado (Marín López, 1994a, 1994b; Moya del Baño, 1986; Elvira, 2015). Procede siempre según una pauta bien definida: propone primero un «estado de la cuestión», lo más completo posible, clasificando la posición de las autoridades sobre un tema en particular y ordenándolas por orden cronológico. Después analiza estas ideas y se decanta por una en particular. Dicho método supone tener acceso a una gran cantidad de libros, sea de su propia biblioteca, sea de otras bibliotecas físicas, privadas o «semi-públicas», me refiero a las de los grupos sociales a los que pertenecía como racionero de la iglesia de Córdoba y antiguo alumno de los jesuitas. Antes de centrarnos en la biblioteca personal del abad de Rute, será necesario decir algunas palabras de algunas bibliotecas materiales que marcaron su vida de erudito.

\section{El abad de Rute: bibliófilo y archivero}

4 Los escasos datos que conocemos de la vida de don Francisco (Alonso, 1982b; Molina Recio, 2011; Elvira, 2015) permiten pensar que los libros lo acompañaron a lo largo de su vida. Las mayores incógnitas corresponden a los años 1590-1603 que don Francisco pasó en Roma, a la sombra de su primo, el V duque de Sessa, embajador de España en la Santa Sede: ¿sería allí un simple estudiante? ¿capellán? ¿secretario? ¿bibliotecario? Es probable que haya tenido alguna parte en la construcción de la inmensa biblioteca del duque de Sessa, cuya existencia conocemos por el testamento del duque, que la legó a su hijo don Hernando, canónigo en Salamanca (González de Amezúa y Mayo, 1935-1943: vol. 1,

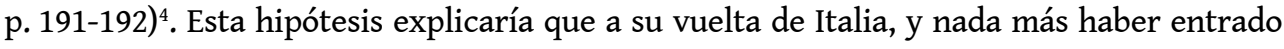
en el cabildo de la catedral de Córdoba en $1603^{5}$ con recomendación del duque, los canónigos le confiaran la catalogación del archivo y de la biblioteca de la catedral, como veremos a continuación. Alguna experiencia previa, forjada en Italia, debió de tener. Además varias de las obras que cita don Francisco en sus trabajos posteriores van precedidas de una dedicatoria al V duque de Sessa, como si hubiera seguido de cerca el mecenazgo que ejerció en Roma su primo ${ }^{6}$.

5 Los canónigos de la catedral de Córdoba supieron aprovechar la familiaridad de don Francisco con los libros y la documentación de archivos. En 1604, le encargaron a él y a otro compañero suyo la realización de un Libro índice de los instrumentos del Archivo ${ }^{7}$, como rezan las Actas capitulares del 12 de julio de 1604 y las primeras páginas del Índice que reproducen la cita:

En la ciudad de Córdoba, a doce días del mes de julio, año de mil y seiscientos y catorce, los señores doctor don Alonso de Miranda, chantre en la Santa Iglesia de Córdoba, y don Francisco Fernández de Córdoba, racionero en ella, diputados por los señores doctor y cabildo de la dicha Santa Iglesia para ver e inventariar todos los privilegios, escrituras, donaciones, títulos, posesiones, e otros papeles convenientes y tocantes a los privilegios y derechos de su Mesa Capitular, como de los diezmos y ejecutorias contra alguna personas ganadas, en esta y otra materia, para y cuando sea necesario aprovecharse de ellas, se hallen con facilidad y distinción, por sus cajones rotulados con las letras del A.B.C. y por cada una de las letras se entenderá la materia de los papeles que están en cualquiera de los dichos cajones, y 
poniéndolo en efecto el dicho día comenzaron por el cajón de la letra JHS en la

forma siguiente (Libro índice, tomo 1).

Se trata de un índice temático, que ordena los documentos en función de su naturaleza y no de su fecha. El orden alfabético es una convención arbitraria para imponer un «orden» en un caos de documentos que clasificar. Es un simple medio mnemotécnico, sin carácter científico ni pretensión universalista, para recordar a los usuarios del archivo qué va en cada sección. Así, en el cajón L se encuentran: «libros Luminarios de repartimiento y memorias de pleitos y quitanzas comunal (sic.)», en el cajón 0: «Todas las fundaciones y dotaciones de Obras pías», en el cajón P: «todos los Privilegios concedidos al Cabildo de esta Santa Iglesia por los reyes pasados y confirmaciones dellos hasta el rey Felipe tercero que hoy vive y viva muchos años», etc. Cuando un cajón estaba completo y no cabían más documentos en él, se abría otro nuevo, con una letra del final del alfabeto, lo que confirma el carácter absolutamente arbitrario de la clasificación. Por ejemplo el cajón $\mathrm{Z}$ contiene: «los libros de los actos Capitulares que no cupieron en el cajón $\mathrm{Q}^{8}$, donde están los demás así antiguos como modernos». El orden alfabético también es alterado en el primer cajón que lleva el nombre de J.H.S. (Ihesus Hominum Salvator), en una voluntad de homenajear al Creador, origen de todo y, ende, inicio de cualquier listado. Ofrece, de paso, una solución cómoda para guardar en él documentos antiguos no claramente identificados: «En este cajón JHS están arrendamientos, títulos de casas que el cabildo posee aunque en nombre de las personas que las vendieron, trocaron o donaron que, por no saberse con distinción cuales sean, quedó así confusamente».

6 Este Índice es un manuscrito empergaminado de dos volúmenes, con numerosos folios en blanco, lo cual demuestra que se preveía irlo completando sobre la marcha. Su estado de conservación, con los bordes ennegrecidos por las numerosas manipulaciones, demuestra que fue la base de las consultas en el archivo, hasta la redacción del catálogo del siglo XVIII - Se distinguen numerosas caligrafías en el manuscrito, de diferentes épocas, con apostillas y comentarios en los márgenes que completan, precisan o corrigen la información. Entre todas las manos que lo redactaron está la del abad de Rute, cuya letra fina, diminuta y regular se reconoce de manera inconfundible en algunas páginas del volumen 2, lamentablemente no numeradas. Eso deja pensar que se trata de una labor colectiva que supervisó nuestro erudito, pero que no fue él quien copió directamente la mayor parte de las referencias. Todo esto hace que don Manuel Nieto Cumplido, actual archivero, a cuya diligencia debemos el conocimiento de este índice, califique a don Francisco de «primer archivero de la catedral», aunque no existiera aún el cargo como tal a principios del XVII.

7 A parte de archivar la documentación del cabildo, también parece que dirigió una catalogación del llamado «fondo antiguo» de la biblioteca del Cabildo que se encuentra todavía hoy dentro de la catedral. De aquella época parecen ser las signaturas todavía visibles (A seguida de números arábigos) en una gran cantidad de manuscritos e incunables 9 . Entre otras cosas, hay en esta biblioteca innumerables ediciones y comentarios de la Biblia, con sus respectivos glosarios, que pudo utilizar el abad de Rute en los capítulos de la Didascalia multiplex dedicados a explicar lugares de los textos sagrados.

8 Además de la biblioteca de la catedral se hallaba en Córdoba la también copiosa biblioteca de humanidades del seminario de los jesuitas, el llamado colegio de Santa Catalina, con su riquísimo fondo de letras humanas ${ }^{10}$, mucho más extenso que el de la biblioteca de la catedral. Como lo veremos a continuación, el abad de Rute mantenía contactos estrechos 
con numerosos jesuitas que le recomendaban libros nuevos para comprar. Es lícito imaginar que pudiera hacer alguna consulta en esta biblioteca. Estaba también en Córdoba la llamada «biblioteca episcopal», situada enfrente mismo de la catedral, en el palacio del obispo, con un vasto fondo de ciencias eclesiásticas, derecho civil y canónico, historia civil eclesiástica y humanidades, catalogado en el siglo xvIII. Así que de libros prestados no carecía nuestro erudito para llevar a cabo sus investigaciones.

Ahora bien, lo que nos va a interesar en este artículo es más bien la biblioteca personal de don Francisco, que estaba en Rute. Disponemos, para tratar de reconstruirla, de unos documentos de gran interés, que son las cartas eruditas que don Francisco mandó a sus corresponsales desde Rute, dado que en esta pequeña ciudad de la provincia de Córdoba no podía disponer de más bibliotecas que de la suya. El Parecer que remitió don Francisco a Luis de Góngora entre finales de 1613 y principios de 1614 es una de ellas: la edité recientemente en el marco de un proyecto dirigido por Mercedes Blanco ${ }^{11}$, y en esta ocasión tuve la oportunidad de reconstruir una mínima parte de la biblioteca de don Francisco, estudiando las fuentes empleadas por don Francisco para comentar literatura (Elvira, 2015).

10 Propongo en este artículo aplicar el mismo método con otras cartas eruditas, las que remitió don Francisco a Pedro Díaz de Rivas, otro participante de la polémica gongorina, también defensor de Góngora, entre 1620 y 1626, acompañadas de una sola carta de 1617. Se sabía de la existencia de estas cartas por Dámaso Alonso, quien ofreció en 1975 una edición muy parcial, porque solamente le interesaban aquellos fragmentos en los cuales el autor del Parecer y del Examen hablaba de Góngora y de la polémica gongorina (Alonso, 1982a). He trabajado por mi parte a partir de la totalidad de las 49 cartas autógrafas de don Francisco, reunidas en un manuscrito que se conserva hoy en la Hispanic Society of America de Nueva York (ms. B3566). No nos llegaron las cartas de Díaz de Rivas.

11 Presentaré rápidamente esta correspondencia para introducir su estudio. Todo apunta a que el abad de Rute y Díaz de Rivas se conocieron a raíz de su participación activa a la defensa de Góngora y que la primera carta conservada de 1617 es una de las primeras que intercambiaron. En efecto, se observa una diferencia notable entre ésta, de tono cordial pero un poco distante, dedicada exclusivamente a la organización de la defensa de Góngora, y las demás cartas que conservamos a partir de 1620, en las cuales el trato es más caluroso y familiar, y el tema de la polémica gongorina casi ha desaparecido. La amistad ya se alimenta de otros gustos compartidos: la literatura al principio y, cada vez más según va pasando el tiempo, la investigación histórica y arqueológica, es decir, lo que se llamaba entonces las antigüedades.

La diferencia de edad entre Díaz de Rivas y el abad de Rute es clave para entender la relación entre los dos hombres. Veinte años mayor que Díaz de Rivas, don Francisco gozaba entonces de renombre y prestigio como erudito, cuando su corresponsal no había producido aún ninguna obra de relieve. En la mayoría de estas cartas, Francisco Fernández de Córdoba contesta a las preguntas de Díaz de Rivas, le da referencias bibliográficas precisas para que pueda completar «sus estudios», relee y corrige sus libros, con una amistosa severidad, que combina exigencia científica y mensajes de aliento. A cambio, Díaz de Rivas se ofrece para comprar libros y facilitarle informaciones sobre las «novedades» y los «libros curiosos» que han salido en las librerías de Córdoba, donde residía. Las cartas ofrecen entonces una doble fuente de información sobre la biblioteca del abad de Rute: a través de los pedidos de libros que el abad de Rute remite a Díaz de Rivas nos enteramos de qué libros adquirió; y, por otra parte, las respuestas del abad de 
Rute a las preguntas de erudición de Díaz de Rivas o sus correcciones nos revelan qué libros Francisco Fernández de Córdoba ya tenía a su disposición en su biblioteca personal de Rute. En efecto en todas las cartas escritas fuera de Rute se disculpa por no poder contestar y promete hacerlo en cuanto vuelva cerca de sus libros: «pésame de no poder ayudar ahora con lo que manda vuestra merced por estar fuera de Rute donde tengo todas mis monedas y los libros dellas» (Carta $n .^{\circ} 11$, Granada, 23 de agosto de 1622). Estudiaremos a continuación primero lo que sabemos de su biblioteca ya constituida $\mathrm{y}$, después, cómo se completó con adquisiciones en el periodo de 1620-1626.

\section{La biblioteca personal de don Francisco}

13 La edición de las cartas del abad de Rute -todavía en curso ${ }^{12}$ - permite al estudioso reconstruir la biblioteca que consultó don Francisco para componerlas, con un nivel de precisión sorprendente, que nos brinda la oportunidad de deshacer o rehacer el camino andado por el autor. Una anécdota que concierne la edición de un fragmento del Parecer permitirá al lector medir hasta qué nivel de detalle podemos llegar en la reconstrucción de la biblioteca material de don Francisco ${ }^{13}$ :

[...] el demasiado cuidado descubierto hace parecer después las cosas con menos gracia y venustidad, como hechas a fuerza, según dijo Apeles a Protógenes viendo aquella excelente pintura de Yáliso, en que había gastado siete años; refiérelo Eliano, libro 12 (sic.), capítulo 12 De varia historia (Elvira, 2015: f. 138 v).

14 La manera de citar la obra de Eliano, numerando los capítulos, nos indica sin lugar a dudas que el abad de Rute consultó una edición bilingüe griego-latina de 1600, pues es la única que incluya números de capítulos: Aeliani variae historiae libri XIIII [...] editio postrema multo quam antehac emendatior, Lugduni: apud Joan. Tornaesium, $1600^{14}$. Además, el abad de Rute reproduce un pequeño error de impresión de la página 328 de la citada edición, donde se cuenta la historia del pintor Yáliso: el número del capítulo 41, impreso en números romanos (XLI) en el margen superior, se lee mal y se parece a un XII. Al copiar la referencia, el abad de Rute se dejó engañar por el defecto de impresión y transcribió una referencia errónea. Anécdota graciosa, grata para el investigador, que no tiene otro interés que de demostrar la honradez intelectual de este hombre, cuyos pasos por su biblioteca podemos seguir con precisión, porque su erudición es de primera mano, fruto de un contacto directo con los libros.

Aclarado el método que hemos seguido, procuraremos sacar algunas conclusiones sobre el contenido de esta biblioteca. Empecemos con la sección de literatura, sobre la cual pasaremos rápidamente, porque ya la describimos en otra ocasión (Elvira, 2015: apartado 5 de la introducción ${ }^{15}$ ). La estancia en Italia marcó profundamente a don Francisco y seguramente haría allí acopio de muchos libros. Tiene en su biblioteca numerosas ediciones de poetas italianos en lengua original: Dante, Petrarca citado en una edición comentada por Alessandro Vellutello, Tasso, Luigi Alamanni, Marco Rosiglia ${ }^{16}$, etc.; así como poesía neolatina italiana: Poliziano, Sannazaro; y poesía latina o griega traducida al latín: Horacio, Virgilio, Ovidio, Estacio, Teócrito, Calpurnio, etc. Por otra parte el conocimiento de las polémicas italianas constituye la base de su reflexión sobre la literatura. Por ejemplo desanima a Díaz de Rivas de escribir un opúsculo contra las obscenidades de Ariosto porque dice:

[...] vuestra merced se puede ahorrar de semejante trabajo, porque el Ariosto está muy bien opinado en materia de poesía y le han defendido de algunas [acusaciones], 
o sean calumnias o detracciones, muy doctamente hombres eruditísimos como: Francisco Patricio, el que escribió de República, de Regno y de Arte poética; Orazio Ariosto, sobrino de Ludovico; el Porta [...] y algunos otros, pero últimamente la Academia de la Crusca de Florencia (Carta n. ${ }^{\circ}$ 5, Rute, 17 de agosto de 1620).

Son libros que tiene indudablemente en su biblioteca y cuyo contenido conoce a fondo, como lo confirma el análisis de las fuentes de la Didascalia multiplex, del Parecer y del Examen (Elvira, 2016).

Otra característica que marca la biblioteca de humanidades del abad de Rute es su pertenencia a la Iglesia que imprimió una profunda huella en su cultura literaria. Los Padres de la Iglesia son autoridades utilizadas frecuentemente para reflexionar sobre la literatura. Ya en el Parecer, cuando el abad de Rute se preguntaba si la oscuridad era lícita en literatura cuando un autor no hablaba de «los misterios de la religión», acudía a San Jerónimo (Elvira, 2015: f. 137r). Y ahora, cuando Díaz de Rivas le pregunta qué «autores [... ] han dicho mal de las comedias y el verlas y oírlas», cita a los padres de la Iglesia que condenaron los espectáculos y el circo:

*Tertuliano, Apologeticus adversus gentes. De spectaculis.

*San Agustín, Epistolae. De civitate Dei.

*San Agustín, De verbis domini et apostoli sermones.

*San Juan Crisóstomo, Epistolae. Homiliae. Commentarius in Psalmos.

Carta n. ${ }^{\circ} 2$ (Rute, 29 de junio de 1620).

En cambio para defender la licitud de escribir poesía muestra que su cultivo era frecuente entre innumerables santos y «hombres píos», lo que le da legitimidad:

Y de la poesía muchos autores han hecho tratados, antiguos y modernos, pero basta para calificación suya que san Gregorio Nacianceno haya hecho la Tragoedia, Christus patiens y el libro de sus poemas sagrados y morales que yo tengo; San Ambrosio, tantos himnos; San Dámaso, tantos versos; San Paulino, las epístolas que andan con las obras de Ausonio; San Próspero, los epigramas; San Alchimo Avito, los libros De paradiso in verso; y los suyos, los hombres píos Prudencio, Sedulio, Juvenco, Arator, Teodulfo, Boecio y Elpis su mujer; por no decir del santo profeta David y de Moisés, que compuso en verso parte del Libro de Job (Carta n. ${ }^{\circ}$ 2, Rute, 29 de junio de 1620).

Nada indica que el abad de Rute tuviera cada una de estas referencias en su biblioteca salvo cuando dice explícitamente que tiene algún libro en concreto- porque para elaborar esta lista bien pudo consultar algún instrumento de erudición de segunda mano o alguna antología ${ }^{17}$. Nos indica en todo caso cuánto se estimaba en aquel tiempo una producción poética que hoy hemos olvidado por completo, la de los himnos y de la lírica religiosa alegórica. De forma comparable, en el Parecer, citaba entre una lista de poemas bucólicos, y en pie de igualdad con las obras de Virgilio y Teócrito, el Carmen bucolicum de virtute signi crocis Domini de Severo Santo Endelequio, también conocido como De mortibus boum («De la mortandad de los bueyes»), una apología del cristianismo bajo la apariencia de una fábula bucólica.

Nos detendremos más tiempo en la sección de historia de la biblioteca del abad de Rute, porque su conocimiento es la gran novedad que proporciona el análisis de las cartas a Díaz de Rivas. Lo primero que se puede apuntar es que la biblioteca del abad de Rute no constaba solamente de libros. También había documentos que él sacaba libremente de los archivos a los que acudía (¡sueño del investigador moderno!), concretamente de los archivos de Baena, Lucena, Luque, Córdoba (éste último, el de la catedral, al que conocía perfectamente por haberlo catalogado). Los tenía en casa un tiempo para copiarlos tranquilamente y tenerlos a disposición para su propia investigación o la de sus amigos, y los devolvía después: 
[...] me aprieta el trasladar ciertos papeles de la Casa de Córdoba que se han de volver a los archivos de Baena (Carta n. ${ }^{\circ}$ 17, Rute, 11 de abril de 1623).

A lo que vuestra merced quiere saber de lo que dice el papel de los archivos de Lucena acerca del mayordomo Luis de Godoy, digo que [...] (Carta n. ${ }^{\circ} 44$, Rute, 27 de octubre de 1625).

En una de sus cartas desaprueba la elección del tema de «estudios» de su corresponsal Díaz de Rivas estaba trabajando sobre la figura de San Hiscio- porque su fuente principal de informaciones iban a ser las crónicas del seudo-Dextro, sobre cuya autenticidad pesaban dudas más que razonables:

Vuestra merced ha tomado difícil asunto, estando pendiente aún la certidumbre destos libros y lo que dicen contra ellos el Padre Casas y [los] que los han interpretado. Yo con mi Casa de Córdoba me loé que tiene poco que dudar (Carta n. ${ }^{\circ}$ 24 , Rute, 29 de julio de 1624).

En cambio, alguno meses después, cuando el joven Díaz de Rivas le comenta que se dispone ahora a escribir la historia de la Casa del duque de Alcalá, don Francisco lo felicita y anima:

El asunto de describir la Casa del duque de Alcalá [...] es muy bueno y que sin duda lo agradecerá el duque mucho y dará el material, pues sin los archivos y papeles destos señores mal con las historias solas se puede hacer cosa que valga. Los Nobiliarios ayudan y destos hay en Córdoba en poder de don Francisco del Corral uno bueno, pero lo que hace al caso es ver los papeles de los archivos y, vistos, disponerlos y adornarlos vuestra merced, que así he hecho yo en mi Casa de Córdoba (Carta n. ${ }^{\circ}$ 25, Rute, 26 de agosto de 1624).

Por su fe en las fuentes documentales de primera mano a las cuales da más importancia todavía que a los trabajos de los historiadores, se puede decir que tiene un acercamiento casi positivista a la historia.

Otra fuente de información, comparable a la de los archivos y más fidedigna que los libros, antiguos o modernos, son para él las inscripciones que se encuentran en las viejas piedras, tan visibles en el paisaje urbano de Córdoba:

[...] la autoridad de las piedras verdaderas es la mayor que puede ser, y más la de las que se hallan en despoblados, porque a los lugares grandes pudiéronse traer de otras partes para edificios, pero las enterradas en ruinas antiguas, ¿quién las pudo llevar allí, sino el que para allí las labró? (Carta n. ${ }^{\circ} 22$, Rute, 17 de marzo de 1624).

Podemos decir que estas inscripciones formaban parte de su biblioteca en sentido propio porque tenía diferentes libros que las recopilaban. El primero de ellos, al que se remite siempre, son Las antigüedades de las ciudades de España que van nombradas en la Coronica con la averiguación de sus sitios y nombres antiguos de Ambrosio de Morales (Alcalá de Henares: Juan Íñiguez de Lequerica, $1575\left(1577^{18}\right)$ o, para el caso de las inscripciones de Roma, las Epigrammata antiquae Urbis de Jacopo Mazzochi (Romae: in aedib. Jacobi Mazochii, 1521).

Pero la epigrafía es una ciencia exigente y más de una vez el abad de Rute desaprueba la manera como la ejerce Díaz de Rivas, demasiado atrevido en sus interpretaciones que parecen ser a veces «adivinanzas» azarosas. Así, después de haber corregido un trabajo poco prudente de Díaz de Rivas, reflexiona:

[...] esto de piedras, y más no enteras, está muy sujeto a adivinanza, y aun las enteras lo están, parte por ignorarse hoy las familias españolas, parte por la mala ortografía de los que abrían las inscripciones; yo me holgara de ser Edipo para desatar estas dudas, pero no tengo lugar aun para pensar en ellas (Carta $n .^{\circ} 38$, Rute, 2 de junio, 1625).

Para un hombre tan riguroso como el abad de Rute, «adivinar» es una tarea grata, lúdica, estimulante intelectualmente, pero poco seria y desprovista de validez científica. Cuando Díaz de Rivas le pregunta su parecer sobre una cuestión de erudición y no puede 
contestar porque carece de pruebas, más de una vez se niega a «adivinar» de manera indebida: «Que midiesen hasta la puente [...] o no: no sé; parecer adivinar el afirmarlo» (Carta n. ${ }^{\circ} 33$, Rute, 11 de febrero de 1625); «así que todo esto es adivinar, y lo que se puede afirmar es que Tarifa no fue Carteia, pero cuál fuese, ad hoc sub judice lis est» (Carta n. ${ }^{\circ}$ 18, Rute, 25 de abril de 1623).

Finalmente, la última fuente de información semejante a la de las inscripciones y documentos de archivos, son las medallas y monedas antiguas, de las que tiene una gran colección en lo que él llama el «museo» de su biblioteca del que hace mención en la carta n. ${ }^{\circ} 20$ (Rute, 5 de diciembre de 1623). Son también documentos fidedignos que proporcionan informaciones sobre las ciudades donde fueron emitidas: dónde se situaban, cuándo fueron fundadas, qué divinidad se veneraba en ellas. El abad de Rute coteja sus propias monedas y medallas con las reproducciones que ilustran los hermosos libros que tiene. Maneja en este caso una bibliografía muy completa: Antonio Agustín ${ }^{19}$, Hubertus Goltzius ${ }^{20}$, Constanzo Landi ${ }^{21}$, Fulvio Orsini ${ }^{22}$ y Enea Vico ${ }^{23}$.

21 Por su metodología y la fe que tiene en las fuentes materiales (archivos, monedas, inscripciones, restos de vajilla), el abad de Rute se sitúa en la línea de un Ambrosio de Morales, paisano suyo de Córdoba, al que pudo conocer personalmente en su juventud ${ }^{24}, \mathrm{y}$ por el que profesaba una gran admiración ${ }^{25}$. Las herramientas que utiliza don Francisco en sus investigaciones son las mismas que las que describe Morales en el «Discurso general sobre las antigüedades, donde se enseña la manera de bien averiguarlas y entenderlas» que abre Las Antigüedades de las ciudades de España. Como su maestro, don Francisco utiliza frecuentemente el Itinerario del Emperador Antonino, un documento del siglo III, en el que aparecen recopiladas las rutas del imperio romano y las distancias entre las diferentes ciudades ${ }^{26}$. Copia fragmentos enteros de esta obra para Díaz de Rivas, que por lo visto no la tenía, con listas de ciudades y su distancia con respecto a un determinado punto. Este libro es su «carta de marear» entre todas las autoridades que se contradicen para ubicar una ciudad en concreto (Carta n. ${ }^{\circ} 20$, Rute, 5 de diciembre de 1623).

También tiene mucha fe en los geógrafos antiguos, griegos y romanos: Ptolomeo, Dionisio de Halicarnaso, Estrabón, Pomponio Mela, así como el Plinio de la Historia naturalis. Dispone de varias ediciones de estos autores: «Digo que vuestra merced opone bien de su Plinio que lee [...]. Así lee otro mío y aún otro, impreso en Venecia» (Carta n. ${ }^{\circ} 21$, Rute, 19 de diciembre de 1623). A Estrabón, lo lee en una traducción al latín de Guilielmus Xylander recogida en la edición comentada de Isaac Casaubon ${ }^{27}$ y la coteja sistemáticamente con otra traducción al latín de Guarino Veronese y Gregorio Trifernate ${ }^{28}$ (Carta n. ${ }^{\circ} 36$, Rute, 4 de mayo de 1625). En cuanto a Ptolomeo, lo consulta en edición de Miguel Servet ${ }^{29}$ (Carta $n .{ }^{\circ} 22$, Rute, 17 de marzo de 1624) y en otra más moderna con comentarios de Giovanni Antonio Magini ${ }^{30}$ (Carta n. ${ }^{\circ} 23$, Granada, 21 de mayo de 1624). El valor de una edición reside para él en la fiabilidad del texto editado y en la calidad del aparato de notas y variantes que acompaña el texto. Por eso se alegra tanto cuando Góngora le envía desde Madrid «dos libros que [...] deseaba y había menester, y son los mejores que han salido a luz hasta ahora en su género, el uno es Dionyssio Halicarnasseo antiquitatum romanarum ${ }^{31}$ y el otro las Historias de Dion Cassio ${ }^{32}$, ambos grecolatinos y con anotaciones de modernos» (Carta n. ${ }^{\circ} 1$, Granada, 25 de julio de 1617). Cuando sale una edición mejor que la que tiene él, no duda en «feriar» es decir cambiar el ejemplar viejo por otro nuevo ${ }^{33}$. Estos geógrafos antiguos son cotejados sistemáticamente con los trabajos de los modernos, Abraham Ortelio y Luis Núnez por ejemplo. 
iamente posee en su biblioteca, y los utiliza como fuente habitual de sus investigaciones, historiadores antiguos, griegos y latinos: Apiano de Alejandría, Polibio, Diodoro de Sicilia, Casiodoro, Pablo Orosio, Rufino de Aquilea, Sexto Aurelio Víctor, Tito Livio, Veleyo Patérculo; así como historiadores medievales: Nicéforo Calixto, Jorge Cedreno, Pablo el Diácono, Juan Zonaras. Es particularmente experto en la historia de la Iglesia, con un particular énfasis en los primeros tiempos del cristianismo. Al igual que Ambrosio de Morales se interesa por el culto de los santos. Dispone de una decena de santorales, flores sanctorum, breviarios y martirologios; y más de una vez lamenta su escasa fiabilidad. Naturalmente las crónicas de todas las épocas y las historias modernas abundan, aunque como veremos esta parte de la biblioteca fue la que más se amplió en el periodo de 1620-1626 con las adquisiciones que estudiaremos más adelante.

terminar señalaremos una característica general que marca el contenido de esta biblioteca. Los libros de antigüedades versan sobre el estudio de dos zonas geográficas bien definidas: Roma y Andalucía, dos lugares en que residió y donde el pasado romano afloraba en cada esquina. Seguramente el abad de Rute prolongó en España unos estudios empezados en Roma. Autores como Onufrio Panvinio ${ }^{34}$ o Guido Panciroli ${ }^{35}$ contribuyeron a su formación de anticuario. Una vez de vuelta a Andalucía, siguió comprando los estudios más recientes sobre las antigüedades de diferentes ciudades ibéricas, con una concentración de estudios sobre las ciudades andaluzas: Bernardo Aldrete ${ }^{36}$, Bermúdez de Pedraza $^{37}$, Rodrigo Caro ${ }^{38}$, Luis Núñez ${ }^{39}$ y obviamente los trabajos de Díaz de Rivas ${ }^{40}$. Cabe observar que desde la perspectiva de don Francisco el estudio de las antigüedades se confunde con el de la genealogía. En su descripción de la Casa de Córdoba, el estudio de las vicisitudes de los miembros de esta familia se mezcla y superpone con el estudio de la fundación de la ciudad y su historia. La Casa de Córdoba es la ciudad de Córdoba y Córdoba es la Casa de Córdoba. Son reveladoras las líneas siguientes dirigidas a Díaz de Rivas para animarle a seguir con sus estudios: «Muy bien hace vuestra merced en escudriñar tan de propósito las antigüedades de nuestra Córdoba para honrarla con ellas y a su tiempo para mostrar al mundo ejecutoría tan antigua de su nobleza» (Carta n. ${ }^{\circ} 38$, Rute, 2 de junio de 1625). Estudiar la arqueología de Córdoba y estudiar los orígenes de su nobleza: todo uno.

\section{Las adquisiciones del periodo 1620-1626}

\section{Organización de los pedidos}

Aparentemente, no existía en Rute, pequeña ciudad de la provincia de Córdoba, ninguna librería o, si existía, no estaría suficientemente abastecida. Por eso Fernández de Córdoba le encargaba a Díaz de Rivas, que residía en Córdoba, la compra de los libros que le hacían falta. Obviamente Díaz de Rivas no fue el único proveedor de libros del abad de Rute, pues en las cartas hay alusiones a libros que le llegan por otros medios: regalos de amigos ${ }^{41}$, libros encargados en Granada o Madrid, viajes personales del abad de Rute en los que acude él mismo a librerías, etc. Por ejemplo aprovechó uno de sus viajes a Baena para abastecerse de libros para él y para sus amigos:

Estuve en Baena estos días atrás y allí vi León el librero con libros. Comprele cuatro más Antigüedades de Utrera ${ }^{42}$, otras de Tarragona, Philosophia sacra de Valles ${ }^{43} \mathrm{y}$ un toscano de cibi. Comprárale algunos más de derechos, si no temiera verme sin dinero y fuera de mi casa [...] Encarguele a León me procurase la África de Mármol $^{44}$, porque la he menester para algunas cosas de la Casa de Córdoba, cuando llegue a los

ILCEA, 25 | 2016 
condes de Alcaudete y a los marqueses de Comares (Carta n. ${ }^{\circ} 19$, Rute, 14 de noviembre, 1623).

«León el librero» se perfila como una figura conocida y familiar para los dos corresponsales.

Pero en el periodo que cubren las cartas $(1620-1626)^{45}$, el abad de Rute, ya mayor, viajaba menos de lo que solía hacer antes. En una carta confiesa que ya no sigue tanto la actualidad editorial: «a la librería ${ }^{46}$ no voy como solía, y así no conozco al libro que dice vuestra merced» (Carta n. ${ }^{\circ}$ 23, Granada, 21 de mayo de 1624), lo cual nos da un testimonio de que sí lo solía hacer con asiduidad en épocas anteriores. Por eso, Díaz de Rivas se convirtió en esta etapa de su vida en su principal proveedor de libros. La califica de «zahorí» de libros, le pide mil veces, de manera muy insistente, que le «saque de bajo de la tierra» los libros que necesita (Carta $n .^{\circ} 21$, Rute, 19 de diciembre, 1623). Y para pagarle el tiempo que pasa haciendo diligencias por él, el abad de Rute pone su erudición y su pericia al servicio de su joven amigo: son favores recíprocos y ninguna de las dos partes debe ser deudora de la otra ${ }^{47}$.

El proceso de adquisición de los libros es doble: o el abad de Rute pide títulos específicos, en relación con sus «estudios», y en este caso suele precisar que los necesita para su Casa de Córdoba; o Díaz de Rivas le sugiere compras, mandándole listas de libros disponibles a la venta, con precios, para que pueda elegir:

[...] la Historia de Santiago por don Mauro ${ }^{48}$ tomaré y podrá vuestra merced remitirla con los otros y así mismo me la ${ }^{49}$ hará de enviarme lista de esas Crónicas que, dice, le quieren vender, para que yo vea si me falta alguna dellas, y mándeme en qué le sirva (Carta $n .^{\circ} 26$, Rute, 10 de septiembre de 1624).

Agradezco la voluntad con que vuestra merced me la $^{50}$ hace en todas ocasiones, y en particular cuesta de los libros. Si los Zuritas ${ }^{51}$ nos dieren en buen precio se tomarán, y los Baronios $^{52}$ en todo caso. Holgara ver la lista de los libros curiosos, si vuestra merced puede remitírmela (Carta $n .^{\circ} 41$, Rute, 7 de julio de 1625).

Vuestra merced me procure una lista de los demás libros curiosos del Inquisidor y vea si tenía algunos el doctor Contreras (Carta n. ${ }^{\circ}$ 44, Rute, 27 de octubre de 1625).

A cada solicitud del abad de Rute responde fielmente Díaz de Rivas, mandando la lista en cuestión, de la cual no disponemos, aunque sí llegamos a reconstruir los títulos efectivamente pedidos por don Francisco en la mayoría de los casos:

[...] y agradezco a vuestra merced el cuidado de avisarme qué libros hay de nuevo que comprar. De los que vuestra merced me avisa por la suya digo que tomaré o saque vuestra merced para mí la Vida del rey don Juan el 2 de Portugal por Resendio ${ }^{53}$, en portugués, que costará once reales y la Historia Brabantiae por Barlando ${ }^{54}$ en tres reales, y los dará vuestra merced al licenciado Castillo, que me los remita. Y si vuestra merced hallare obras de Pedro Simón Abril en romance o en latín me las procurará comprar (Carta n. ${ }^{\circ} 49$, Rute, 28 de abril de 1626).

Los libros en cuestión a veces son «novedades» recién salidas de la imprenta, pero más frecuentemente son ediciones antiguas, sospechamos que de segunda mano. La bibliofilia del abad de Rute se observa en el afán de reunir colecciones completas, con un criterio de exhaustividad sorprendente. Por ejemplo, respecto al pedido de la Descripción general de África de Mármol, el abad de Rute explica:

El [librero] llevaba un tomo, pero yo los quiero todos, suplico a vuestra merced me los busque y procure juntar para el fin que he dicho, porque voy dando remate a esta obra [la Casa de Córdoba], después que acabe la del Santo Matías (Carta n. ${ }^{\circ} 19$, Rute, 14 de noviembre de 1623). 
[...] digo que agradezco a vuestra merced mucho el cuidado de los Baronios, de que me dice ha hallado diez cuerpos, pero, en no estando el juego cabal, yo no los quiero (Carta n. ${ }^{\circ}$ 44, Rute, 27 de octubre de 1625).

\section{colección:}

Mucho me holgaría que vuestra merced me buscase y hallase por allá (pues le han dicho, según me escribió, que le venderían algunas crónicas) las que le diré ahora: *Primera parte de la Crónica del orden de San Francisco ${ }^{55}$, escrita por aquel portugués fulano de Lisboa y traducida en lenguaje antiguo. Tengo la segunda parte yo.

*Segunda y tercera parte de la Crónica del orden de Santo Domingo ${ }^{56}$, tengo yo la primera y la cuarta ${ }^{57}$.

*Primera parte de la Historia del Rey don Felipe II por Antonio de Herrera ${ }^{58}$. Tengo yo la segunda y tercera parte.

*Primera parte o primer tomo de las Repúblicas del mundo por fray Jerónimo Román ${ }^{59}$. Tengo yo la segunda parte.

*Segunda y tercera parte de la Historia de Garibay ${ }^{60}$; tengo yo la primera y la cuarta y me hacen falta para la historia de España las otras dos, y en particular la que trata de los reyes de Castilla, creo ha de ser la segunda (Carta n. ${ }^{\circ} 27$, Rute, 24 de septiembre de 1624).

La preocupación por el coste de los libros es permanente y crece según van pasando los años, como si su poder adquisitivo se viera mermado al hilo del tiempo, en un movimiento comparable al que sufren las cuentas de su compañero de cabildo, Luis de Góngora:

Hubiérale envidia a los buenos libros que ha visto ahí, pero yo, como vuestra merced dice, me hallo en tan mal estado de comprarles que me holgaré más de no verles, porque si de los ojos nace ver y desear, etc., algún día querrá Dios que podamos (Carta n. ${ }^{\circ} 6$, Rute, 24 de agosto, 1620).

En lo que toca a los Zuritas, tómelos vuestra merced si están cabales y nos les dan en buen precio, [...] y los poetas griegos también, si nos les dan en buen precio, que hoy se halla muy poco dinero, al menos los Zuritas tomaré de buena gana, si nos hacen comodidad, que sí harán, estando vuestra merced de por medio (Carta n. ${ }^{\circ} 39$, Rute, 16 de junio de 1625).

Para los Baronios, si hubiere otros de precio más menudo de los que yo pido, avíseme vuestra merced [...] esto de pocos dineros es el diablo (Carta n. ${ }^{\circ} 40$, Rute, 30 de junio de 1625).

Los Anales de Zurita no sé cómo saldrán por pliego a dos maravedíes. Si los encuaderna sabremos el precio. Vuestra merced haga la diligencia de los Baronios, muy apretada, por su vida, que no querría quedarme sin ellos y vea yo en esto la mucha merced que vuestra merced me hace (Carta n. ${ }^{\circ} 42$, Rute, 25 de agosto de 1625).

31 Otra característica general que podemos observar es que muchas veces compañeros jesuitas intervienen en el proceso de selección de las obras, ejerciendo de prescriptores y asesores para la compra de libros nuevos. Dice así:

De Reginaldo me dicen que hay una Suma famosa ${ }^{61}$, copiosísima y de grande opinión, que la loan en la Compañía: holgaría de haberla (Carta n. ${ }^{\circ}$, Rute, 28 de septiembre de 1620).

En la Compañía vi un librito del padre Roa, de Málaga, en $4^{62}$. Dícenme es curioso leerlo en teniendo lugar (Carta n. ${ }^{\circ} 11$, Granada, 23 de agosto de 1622).

El Padre Santivarios de la Compañía estuvo conmigo ayer y me dijo había salido una historia o Annales ab orbe condito del Padre Saliano ${ }^{63}$ de la Compañía. Dígame vuestra merced si ha visto algo, que me le loó mucho... (Carta n. ${ }^{\circ}$ 19, Rute, 14 de noviembre de 1623). 
32 volúmenes escritos por miembros de la Compañía de Jesús, aunque don Francisco no mencione explícitamente que los pide por recomendación expresa suya. No solo se aplica a los libros de moral, sino también a los de historia, pues muchos jesuitas brillaron en su cultivo. Estos autores conforman una «internacional jesuítica» que promocionaba las obras escritas por sus miembros a una escala global ${ }^{64}$.

El abad de Rute paga los libros a través de «libranzas» que remite a Andrés Díaz de Rivas, mayordomo del cabildo de Córdoba, que por lo visto manejaba algunos de sus intereses ${ }^{65}$.

A Ægidio De sacramentis ${ }^{66}$ he oído alabar, y así se servirá vuestra merced de comprármele. Díceme vuestra merced que costará treinta y seis reales. El señor Andrés Díaz de Rivas me hará merced de darlos (que por ésta digo serán bien dados) a vuestra merced, y los pasaré en cuenta, y vuestra merced mandará remitir el libro o darle al licenciado Castillo, para que le envíe a Baena, al tesorero del duque, que me le guarde (Carta n. ${ }^{\circ} 12$, Granada, 30 de agosto de 1622).

Don Andrés era un amigo personal de don Francisco y el padre de Díaz de Rivas, con lo cual era muy conveniente que todos los trámites de la compra de libros se hicieran dentro de la misma familia. El llamado «licenciado Castillo» mandaba los libros hasta Baena ${ }^{67}$ y después algún «arriero» los llevaba hasta Rute (Carta n. ${ }^{\circ} 15$, Rute, 8 de noviembre de 1622). Es un medio de transporte poco seguro que no permite el envío de libros de valor:

[...] libros destos de mano $0^{68}$ tan raros y de tanta estima no se pueden encomendar a aventuras del camino, que por algún accidente se pierda, sin reparo de hallar otro que comprar. Y así para Antequera me pidieron los días pasados otro de mano el Padre Cabrera y el licenciado Juan de Aguilar y me hubieron de perdonar, diciendo tenía razón de no sacarles de mi poder (Carta n. ${ }^{\circ}$ 47, Rute, 23 de marzo de 1626).

A veces se aprovecha la casualidad de que algún conocido «de cuidado» haga el viaje de Rute a Córdoba y se le confía, además de libros, monedas antiguas romanas, para que Díaz de Rivas las pueda copiar e ilustrar con ellas sus libros ${ }^{69}$. Los demás libros de la biblioteca de Rute circulan mucho, porque don Francisco los pone a disposición de sus amigos. Por ejemplo la Poética de Escalígero hace varias veces el viaje entre Rute y Córdoba:

[...] estando en víspera de un disanto ${ }^{70}$ que yo no querría que llegase (que es ver lo que ha escrito contra mi Apología don Juan de Jáuregui, aunque otros dicen que no ha escrito nada) y habiendo de valerme de Escalígero, se le remito en esta duda. Vuestra merced lo vea y la Apología de don Lorenzo Ramírez contra Radero ${ }^{71}$ y me las vuelva luego, por sí o por no (Carta n. ${ }^{\circ}$ 3, Rute, 7 de julio de 1620).

El abad de Rute mandó a Díaz de Rivas el libro de Escalígero a pesar de que lo pudiera necesitar para preparar una eventual respuesta a algún posible nuevo ataque de Jáuregui (que al final no se produjo), revelando así hasta qué punto valoraba este libro como fuente de informaciones básicas sobre la teoría literaria. Seis años después lo tenía todavía Díaz de Rivas y se lo reclamaba don Francisco. Puede que en el ínterin haya hecho más viajes.

[...] y me importa ver la Poética de Escalígero. Mande vuestra merced enviarme la que tiene allá mía, que, si la hubiere vuestra merced menester, se la volveré a enviar, pues nos hemos de socorrer los de la carda ${ }^{72}$ (Carta n. ${ }^{\circ} 46$, Rute, 9 de marzo de 1626).

Este vaivén de libros prestados entre amigos es una constante. Veamos otro ejemplo: Mucha merced ha héchome vuestra merced en buscar el Fortalitium fidei y me la hará de continuar el buscarle, porque, aunque me le ha enviado de Antequera nuestro amigo Juan de Aguilar, es prestado, y yo le deseo en propiedad para enviarle a don Lorenzo Ramírez de Prado, que me le ha pedido (Carta n. 21 , Rute, 19 de diciembre, 1623).

Un solo ejemplar es leído por numerosos lectores. 


\section{Los libros pedidos}

34 Para terminar, clasificaremos los libros pedidos por el abad de Rute. La primera categoría son libros de moral y casuística. Hasta donde me alcanza, el abad de Rute no publicó ningún tratado de moral y, entonces, no creo que sean compras relacionadas con la preparación de un libro. No se sabe a ciencia cierta si se llegó a ordenar de sacerdote (no era estrictamente necesario ni para ser racionero de la catedral, ni para ser abad mayor de Rute), pero creo que sí lo fue, dada su profunda y sincera devoción y los repetidos consejos que le da a Díaz de Rivas de ordenarse ${ }^{73}$. Abundan entre los pedidos los manuales de instrucción de sacerdotes y las sumas que examinan casos de conciencia. Creo que estas compras corresponden a una curiosidad personal, si bien sorprende la cantidad de libros de este tipo: una veintena de títulos firmados por Alfonso de Arboleda y Cárdenas, Martín de Azpilcueta, Egidio de Coninck, Alonso de Espina, Fabio Incarnato, Leonardo Lesio, Fray Marcos de Lisboa, Luis de Molina, Valerio Reginaldo, Tomás Sánchez de Ávila, Cristóbal de San Antonio, Gregorio Sayro Anglo y Martín Alfonso Vivaldo.

La segunda gran categoría son crónicas, medievales o modernas, que usa directamente para su libro de la Historia de la Casa de Córdoba, como lo dice explícitamente. Dentro de esta categoría, se destaca un subgénero, constituido por las crónicas de diferentes órdenes religiosas y las historias de la Iglesia. No sé para qué las compraría el abad de Rute, si por simple curiosidad o si por algún trabajo en curso del que no tenemos constancia. Parece que estudiaba la historia de las órdenes de forma metódica, una tras otra, para alguna finalidad desconocida. Además, se observa que, cuando el abad de Rute compra lotes de crónicas, compra en realidad libros que dialogan entre sí, a veces de forma poco cordial. La redacción de estas crónicas fue la ocasión de polémicas historiográficas violentas que atestiguaban rivalidades entre las diferentes órdenes religiosas, en particular entre franciscanos y agustinos. El carácter sistemático de las compras parece indicar por parte del abad de Rute una voluntad de reunir todas las piezas de la polémica, que versaba sobre si la orden franciscana era una rama de la orden agustina o no. El abad de Rute podía así cotejar la Crónica de la orden de los ermitaños del glorioso padre Santo Augustín de fray Jerónimo Román donde se afirmaba la supremacía de los agustinos, con la Cuarta parte de la crónica general de nuestro padre San Francisco de Antonio Daza, que incluía en sus preliminares un «Discurso en que se trata si nuestro seráfico padre san Francisco fue fraile de otra religión, antes o después de haber fundado la suya» que le replicaba (Sanz Hermida, 2001).

La reconstrucción de la biblioteca permite esbozar el perfil de un gran erudito, que logró reunir en la pequeña ciudad de Rute una biblioteca impresionante, especializada en letras humanas y antigüedades. Esta biblioteca refleja las andanzas de don Francisco por Italia y España: reunió en ella lo mejor de la tradición humanística italiana con lo mejor de la tradición historiográfica española, heredada de Morales. La lectura de las cartas a Díaz de Rivas muestra también cómo se completó esta biblioteca a partir de una conmovedora relación de amistad que giraba alrededor de esta biblioteca: ésta proporcionaba informaciones y referencias para los estudios de Díaz de Rivas, a cambio de adquisiciones nuevas para las lecturas de don Francisco. 


\section{BIBLIOGRAFÍA}

\section{Manuscritos consultados}

Hispanic Society of America, ms. B3566. Cartas de Francisco Fernández de Córdoba a Pedro Díaz de Rivas.

Biblioteca Nacional de España, ms. 3271, Historia de la casa de Córdoba.

Biblioteca Nacional de EsPaÑa, ms. 2077, Historia de la ciudad de Córdoba y origen de la casa de Alcaudete por el racionero don Francisco de Córdoba.

Biblioteca de la Fundació Bartomeu March, ms. B106-V1-36, f. 131r-145v. Contiene en los folios indicados el Parecer de don Francisco de Córdoba acerca de las Soledades, a instancia de su autor.

\section{Impresos}

Abascal Palazón Juan Manuel (ed.) (2012), Ambrosio de Morales. Las antigüedades de las ciudades de España. Edición crítica del manuscrito, Madrid: Real Academia de la Historia.

ALonso Dámaso (1982a), «Góngora en las cartas del Abad de Rute», Obras completas (t. VI, 219-260), Madrid: Gredos.

Alonso Dámaso (1982b), «Sobre el Abad de Rute: algunas noticias biográficas», Obras completas (t. VI, 203-218), Madrid: Gredos.

ARTigas Miguel (ed.) (1925), Examen del Antídoto o Apología por las Soledades de don Luis de Góngora contra el autor del Antídoto de Francisco Fernández de Córdoba publicado en M. Artigas, Don Luis de Góngora y Argote. Biografía y estudio crítico, Madrid: tipografía de la Revista de archivos, Apéndice VII, 400-467.

GATES Eunice Joiner (1951), «Don Francisco Fernández de Córdoba, defender of Góngora», The Romanic review, 42(1), 18-26.

Elvira Muriel (ed.) (2015), Parecer de don Francisco de Córdoba acerca de las Soledades, a instancia de su autor [1614], Mercedes Blanco (dir.), «Édition digitale et étude de la polémique autour de Góngora», <http://obvil-dev.paris-sorbonne.fr/corpus/gongora/1614_parecer/>.

ELVIRA Muriel (2016), «Des polémiques italiennes aux polémiques espagnoles. L'abbé de Rute, lecteur de Guarini et de Denores», D’une péninsule l'autre : rivalités de plumes entre Espagne et Italie ( $X V^{e}$-XVII ${ }^{e}$ siècles), en prensa.

FERNÁNDEZ DE CóRdoba Francisco (1615), Didascalia multiplex, Lugduni: Sumptibus Horatii Cardon. FERNÁNDEZ DE CóRDoBA Francisco (1954-1972), «Historia de la casa de Córdoba», Boletín de la Real Academia de Córdoba, vol. 71-92, publicada a lo largo de casi veinte años con paginación separada. García y García Antonio, CANTElar Rodríguez Francisco \& Nieto Cumplido Manuel (1976), Catálogo de los manuscritos e incunables de la catedral de Córdoba, Salamanca: Universidad pontificia.

GONZÁLEZ DE AMEZÚA Y MAYo (1935-1943), Lope de Vega en sus cartas. Introducción al epistolario de Lope de Vega y Carpio que por acuerdo de la RAE publica, Madrid: Tipografía de archivos. 
MARÍN LóPEZ Nicolás (1994a), «El humanista don Francisco Fernández de Córdoba y sus ideas dramáticas», N. Marín López, Estudios literarios sobre el Siglo de Oro, 2. ${ }^{\text {a }}$ ed. al cuidado de Agustín de la Granja, Granada: universidad de Granada, 41-63 (1. ${ }^{\mathrm{a}}$ ed. 1974).

MARÍN LóPEZ Nicolás (1994b), «Las ideas poéticas del Abad de Rute», Estudios literarios sobre el Siglo de Oro, 2..$^{a}$ ed. al cuidado de Agustín de la Granja, Granada: Universidad de Granada, 65-91 (1. ${ }^{\text {a ed. }}$ 1985).

MoLina Recio Raúl (2011), entrada «Fernández de Córdoba», Diccionario biográfico español (vol. XVIII, 761-762), Madrid: Real Academia de la Historia.

MoYa DEL BAÑo Francisca (1986), «La Didascalia multiplex de Francisco Fernández de Córdoba: sus aportaciones a la filología clásica», Homenaje a Pedro Sáinz Rodríguez (vol. II: Estudios de Lengua y Literatura, 437-459), Madrid: FUE.

NiETo CUMPLIDo Manuel \& SÁNCHEZ GARCíA Luis Enrique (1981), Inventario de la sección de obras pías de la Catedral de Córdoba, siglo XIV-xx, Madrid: Ministerio de Cultura.

OROzco Emilio (1969), En torno a las Soledades de Góngora, Granada: Universidad de Granada.

Rico GARCía José Manuel (ed.) (2002), Antídoto contra la pestilente poesía de las Soledades por Juan de Jáuregui, Sevilla: Universidad de Sevilla.

RoSES Joaquín (1996), «Francisco Fernández de Córdoba y su contribución al debate sobre el poema lírico moderno", Actas del IV congreso internacional de la Asociación Internacional Siglo de Oro (AISO) (tomo II, 1427-1434), Alcalá de Henares: Universidad de Alcalá.

SANZ HERMIDA Jacobo (2001), «La continuación de las crónicas franciscanas de Marcos de Lisboa: fray António Daza y la Quarta parte de la Chrónica General (Valladolid, 1611)», J. A. de Freitas Carvalho (dir.), Quando os frades faziam história. De Marcos de Lisboa a Simâo de Vasconcelos (83-92), Oporto: Universidad de Oporto.

\section{NOTAS}

1. Agradezco a Anne Cayuela y a Roland Béhar por su atenta lectura del manuscrito.

2. Habla de él en sus cartas a Díaz de Rivas por los años de 1621-1622.

3. Se conservan varios manuscritos, el primero de ellos autógrafo y muy tachado: BNE, ms. 3271, Historia de la casa de Córdoba; BNE, ms. 2077, Historia de la ciudad de Córdoba y origen de la casa de Alcaudete por el racionero don Francisco de Córdoba.

4. Después de la muerte prematura de éste, esta biblioteca llegó a parar entre las manos de su hermano don Luis, sexto duque de Sessa, quien la tenía todavía en sus cajones originales más de quince años después, aunque no leyera ningún título, para la desesperación de su secretario Lope de Vega. Véase carta . $^{\circ} 154$ del epistolario editado por González de Amezúa y Mayo. Véase también la introducción del mismo (González de Amezúa y Mayo, 1935: 191, nota 65) donde se cita el testamento del quinto duque de Sessa.

5. El expediente de limpieza de sangre de don Francisco es de octubre de 1603.

6. Por ejemplo la edición bilingüe griego-latina, de Diógenes Laercio con anotaciones de Aldobrandini en 1594.

7. Los primeros en informar de la existencia de este índice fueron Manuel Nieto Cumplido y Luis Enrique Sánchez García (1981). Lo describen en las primeras páginas del citado trabajo.

8. No hay cajón $C$, por eso los actos capitulares van en el cajón $Q$, por equivalencia fonética entre la «c» y la «q».

9. Así lo sospechan García y García, Cantelar Rodríguez \& Nieto Cumplido (1976: XLIX). 
10. El fondo de esta biblioteca ha llegado a formar parte del actual fondo de la biblioteca diocesana de Córdoba, informatizado <www.bibliotecadiocesanacordoba.es/>. Se pueden extraer los libros que provienen específicamente del colegio de Santa Calina, que son 2204 volúmenes.

11. Proyecto «Édition digitale et étude de la polémique autour de Góngora / Edición digital y estudio de la polémica gongorina», dirigido por Mercedes Blanco dentro del labex OBVIL de la universidad de la Sorbona, disponible en línea: <http://obvil.paris-sorbonne.fr/corpus/gongora/>. Este proyecto se benefició de una ayuda de Estado gestionada por la Agence Nationale de la Recherche cuya referencia es ANR-11-IDEX-0004-02.

12. Preparo actualmente una edición de estas cartas con la identificación precisa de todos los libros solicitados por el abad de Rute o ya poseídos por él.

13. Dicho sea de paso, lo mismo se produce con las cartas a Díaz de Rivas. Cito este ejemplo por su claridad.

14. Sin embargo mantiene el título más común en latín de la obra de Eliano, prueba de su familiaridad con la obra.

15. Se puede consultar en el enlace siguiente: < http://obvil.paris-sorbonne.fr/corpus/ gongora/1614_parecer/front-1>.

16. Hoy completamente olvidado. Don Francisco lo cita por sus églogas, insertas dentro de la siguiente miscelánea: Rosiglia, Marco, Miscelanee [sic] nova del $p$ [re]clarissimo poeta maestro Marcho Rasilia da Foligno et altri auctori [...] Sta[m]pata i[n] Venetia: p[er] Nicolo dicto Zopino, [c. 1510-1515].

17. Existían muchas: Poetae christiani veteres, Venecia, Aldo Manucio, 1501-1502; los Carmina pia et religiosa, editados por Josse Bade, 1505; los Pia et emuncta opuscula editados por J. Toussaint (París: Bade, 1513) o la colección de poemas preparada por Georg Fabricius: Poetarum veterum ecclesiasticorum opera christiana reliquiae atque fragmenta, Basilea, 1564. Nada permite saber qué fuente utilizó.

18. 1575 es la fecha de la portada, aunque en realidad el libro se terminó de imprimir en 1577, como rezan los preliminares.

19. Antonio Agustín Albanell, Diálogos de medallas, inscripciones y otras antigüedades, Tarragona: Felipe Mey, 1587.

20. Hubertus Goltzius, Thesaurus rei antiquariae huberrimus: ex antiquis tam numismatum quam marmorum inscriptionibus [...] conquisitus ac descriptus, \& in locos communes distributus per Hubertum Goltzium, Antuerpiae: ex officina Christophori Plantini, 1579.

21. Constanzo Landi, In veterum numismatum romanorum miscellanea explicationes, Lugduni: Apud Sebastianum de Honoratis, 1560.

22. Fulvio Orsini, Familiae Romanae quae reperiuntur in antiquis numismatibus ab urbe condita ad tempora divi Augusti ex biblioteca Fulvi Ursini. Adiunctis Familiis XXX ex libro Antoni Augustini Ep. Ilerdensis, Romae: Impensis haeredum Francisci Tramezini. Apud Iosephum de Angelis, 1577.

23. Enea Vico, Discorsi di M. Enea Vico parmigiano sopra le medaglie de gli antichi, divisi in dve libri, ove si dimostrano notabli errori di scrittori antichi e moderni intorno alle historie romane, In Vinegia: Appresso Gabriel Giolito de Ferrari et fratelli, 1555. Y del mismo autor: Ex libris XXIII commentariorum in vetera imperatorum romanorum numismata Aeneae Vici liber primus, Venetiis: 1560.

24. Ambrosio de Morales residió en Córdoba entre 1582 y su muerte en 1591 . El abad de Rute nació en 1564 y se educó entre Córdoba y Granada (Elvira, 2015). Salió a Roma en 1590. Son entonces 8 años (1582-1590) durante los cuales pudieron coincidir en Córdoba, viviese o no el abad de Rute en ella a tiempo completo (su madre estaba en algún convento cordobés). Ambrosio de Morales también conoció al joven Góngora, amigo personal de don Francisco y futuro racionero de la catedral cordobesa como él (Artigas, 1925: 26).

25. Lo cita muy frecuentemente y desaprueba explícitamente que Díaz de Rivas lo critique tanto en sus trabajos: «no querría que vuestra merced, como he visto en muchas cosas suyas, se 
opusiese a Ambrosio de Morales, cuando no por tan docto y listo, por compatriota, aunque magis amica veritas» (Carta $n .^{\circ}$ 48, Rute, 28 de marzo de 1626).

26. Itinerarium Antonini Augusti, et Burdigalense. Quorum hoc nunc primum est editum: Illud ad diuersos manusc. codices et impressos comparatum, emendatum et «Hieronymi Suritae», Caesar-augustani, doctissimo commentario explicatum, Coloniae Agrippinae: in officina Birckmannica, 1600.

27. Strabonis rerum geographicarum libri XVII. Isaacus Casabonus [sic] recensuit [...], emendavit ac commentariis illustravit. Accessit et tabula, orbis totius descriptionem complectens; Adjecta est etiam Guilielmi Xylandri, [...] latina versio, cum necessariis indicibus, [Genevae]: excudebat Eustathius Vignon, 1587 (reedición en 1620). Esta obra incluye la primera edición de los famosos mapas de Mercator.

28. Strabonis Geographicorum libri XVII [...] a Guarino Veronensi ac Gregorio Trifernate latinitate donati iam denuo a Conrado Heresbachio, [...] ad fidem graeci exemplaris authorumque, qui huc facere videbantur, recogniti [...] nunc primum de graeco sermone in latinum conuersae, Hieronymo Gemusaeo [...] interprete, Basileae: apud Ioan. Vualder, 1539.

29. Miguel Servet escribía con el seudónimo de Michael Villanovanus: Claudii Ptolemaei Alexandrini geographicae enarrationis libri Octo. Ex Bilibaldi Pirckeymheri Tra[ns]Latione, sed ad graeca \& prisca exemplaria a Michaele Villanovano iam primum recogniti, Lugduni: ex officina Melchioris et Gasparis Trechsel Fratrum, 1535.

30. Geographiae Universae tum veteris tum novae absolutissimun opus duobus voluminibus distinctum, In quorum priore habentur Cl. Ptolomeai Pelusiensis Geographicae enarrationis Libri octo: Quorum primus, qui praecepta ipsius facultatis omnia complectitur, commentariis uberrimis illustratus est a Io. Antonio Magino Patavino, in secundo volumine insunt $\mathrm{Cl}$. Ptolomei antiquae orbis tabulae XXVII ad priscas historias intelligendas summe necessarie [...], Venetiis: apud Haeredes Simonis Galignani de Karera, 1596.

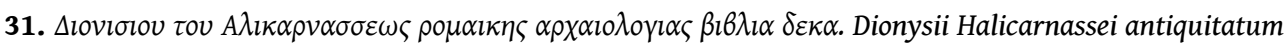
Romanarum Libri X. Ex Bibliotheca Regia. Lutetiae: ex officina Rob. Stephani, typographi regii, typis regiis, 1546.

32. Dion Casio Coceyano, Dionis Cassii Nicaei [...] Romanae historiae libri (tot enim hodie extant) XXV, [...] Giulielmo Xylandro Augustano interprete; his accesserunt eiusdem Annotationes, Basileae: apud Ioannem Oporinum, 1558.

33. «El Suplementum chronicorum tengo, aunque no añadido; holgárame ver ése y, si fuera mejor que el mío, feriarle» (Carta n. ${ }^{\circ} 22$, Rute, 17 de marzo de 1624). Está hablando del Supplementum chronicorum: omnes fere historias quae ab orbe condito hactenus gestae sunt [...] de Giacomo Filippo Foresti (princeps: Venezia, Bernardino Benali, 1483). No sé qué edición se publicaría después con «añadidos».

34. Onuphrii Panvinii Veronensis Augustiniani Reipublicae romanae commentariorum [...] libri tres, a Venezia, per Vincenzo Valgrisi, 1550.

35. Notitia dignitatum, utriusque imperii orientis scilicet et occidentis Arcadii honoriique tempora et in eam G. Panciroli [...] comentarium, Coloniae Allobro: Excudebat Stephanus Gamonetus, 1623.

36. Bernardo Aldrete, Varias antigüedades de España, África y otras provincias, Amberes: Iuan Hasrey, 1614.

37. Francisco Bermúdez de Pedraza, Antigüedad y excelencias de Granada por el licenciado Francisco Bermúdez de Pedraza, natural della, abogado en los reales consejos de su majestad, Madrid: por Luis Sánchez, 1608.

38. Rodrigo Caro, Santuario de Nuestra Señora de la Consolación, Antigüedad de la villa de Utrera y Santuario de las Veredas, Osuna: Juan Serrano de Vargas, 1622.

39. Ludovicus Nonius, Hispania sive populorum, urbium, insularum ac fluminum in ea accuratior descriptio, Antuerpiae: ex officina Hieronymi Verdussi, 1607.

40. Los trabajos de Díaz de Rivas sobre las antigüedades de Andalucía son los siguientes: Patronazgo de san Hiscio por la villa de Tarifa que fue antes la famosa Carteia, obra manuscrita de 1623 
(BNE: ms. 1686); Piedra de Córdoba que es dedicación al emperador Constantino Máximo, ilustrada con explicaciones. Al excelentísimo señor don Fernando Enríquez Afán de Ribera, en Córdoba: por Salvado de Cea Tesa, 1624; Piedra de Córdoba que es memoria de los Godos y elogio de la cruz. Al excelentísimo don Fernando Enríquez Afán de Ribera, en Córdoba: por Salvado de Cea Tesa, 1624 (Se imprimió con el precedente); Relación de algunos edificios y obras antiguas que descubrió el río Guadalquivir cerca de Córdoba con la gran creciente que trujo estos días. A don Francisco Fernández de Córdoba, abad mayor de Rute y racionero de la santa Iglesia de Córdoba, en Córdoba: [por Salvado de Cea Tesa], 1626; Discurso de las antigüedades de Carmona o Excelencias de Carmona obra hoy perdida, mencionada por Fray Juan Salvador Baptista Arellano en su posterior Antigüedades y excelencias de la villa de Carmona, en Sevilla: por Simón Fajardo, 1628, f. 121v.

41. En las cartas hay constancia de que recibe libros regalados de parte de Góngora, Juan de Aguilar, Antonio Fernández de Córdoba, el propio Díaz de Rivas (a parte de los pedidos solicitados por el abad de Rute o del envío de sus obras para que sean revisadas, don Pedro también hace regalos desinteresados de obras susceptibles de interesar a su docto amigo) y otras personas no identificadas.

42. Creo que se está refiriendo a la siguiente obra: Caro, Rodríguez, Relación de las inscripciones y Antigüedad de la villa de Utrera, Osuna: 1620.

43. Francisco Valles, De sacra philosophia, sive de iis quae physice scripta sunt in libris sacris, Francorforti: ex Chalcographia romani beati, imprensis Nicolai Bassaei, 1600.

44. Luis del Mármol Carvajal, Primera parte de la descripción general de África, con todos los sucesos de guerras que ha habido entre los infieles, y el pueblo Cristiano, y entre ellos mismos desde que Mahoma inventó su secta, hasta el año del Señor mil y quinientos y setenta y uno, Granada: René Rabut, 1573. Y del mismo autor: Libro tercero, y segundo volumen de la primera parte de la descripción general de África, con todos los sucesos de guerra, y cosas memorables, Granada: René Rabut, 1573; Segunda parte y libro séptimo de la Descripción General de África, donde se contiene las provincias de Numidia, Libia, la tierra de los Negros, la baja y alta Etiopia, y Egipto, con todas las cosas memorables della, Málaga: Juan René, 1599; Historia de la rebelión y castigo de los moriscos del Reino de Granada, Málaga: Juan René, 1600.

45. Dejando aparte la de 1617, dedicada a comentar temas de la polémica gongorina.

46. En este caso no sé si se refiere a una tienda de libros o a una biblioteca. En efecto en otra ocasión nombra «librería» la biblioteca particular de uno de sus conocidos, al que fue a visitar: «Estuve estotro día en el monte Santo y me holgué de ver la librería de don Pedro de Ávila, abad de aquella casa, que es muy numerosa. Regaláronme» (Carta n. ${ }^{\circ} 23$, Granada, 21 de mayo de 1624). 47. Por ejemplo en la carta $n .^{\circ} 12$ (Granada, 30 de agosto de 1622) se disculpa por no poder contestar a las preguntas de don Pedro porque está Granada, y no tiene acceso a sus libros: «Yo quisiera estar en estado para poder lograr la merced que vuestra merced me hace de avisarme de los libros que hay de nuevo, cosa a que yo soy tan aficionado, pero no se puede ahora lo que se quiere». Y escrupulosamente contesta las preguntas en cuanto vuelve a Rute. También se podría citar la carta $n .^{\circ} 32$ (Rute, 31 de diciembre de 1624): «en esta materia de libros debo mucho a su cuidado de vuestra merced en descubrírmeles, y se lo serviré algún día».

48. Mauro Castellá Ferrer, Historia del apóstol de Jesús Cristo Santiago Cebedeo, patrón y capitán general de las Españas, Madrid: [Alonso Martín de Balboa], 1610.

49. La: la merced

50. La: la merced.

51. Jerónimo Zurita y Castro, Anales de la Corona de Aragón, impresos en Zaragoza: en el colegio de San Vicente Ferrer, por Lorenzo de Robles, 1610.

52. César Baronio, Annales ecclesiastici, auctore Caesare Baronio, Antuerpiae: ex officina Plantiniana, 1597-1612.

53. García de Resende, Vida e feitos del Rey Dom João Segundo publicado en Lyuro das obras de Garcia de Resẽde, Lisboa: Luís Rodrigues, 1545. 
54. Adriano Barlando, Rerum gestarum a Brabantiae ducibus historia, Antuerpiae: [Hadrianus Tilanus, et Joannes Hoochstratanus excudebant], 1526.

55. Fray Marcos de Lisboa, Primera parte de las crónicas de la orden de los frailes menores, en Alcalá: en casa de Andrés de Ángulo, 1562.

56. Hernando del Castillo, Segunda parte de la Historia general de Santo Domingo y de su Orden de Predicadores por [...] fray Hernando de Castillo, de la misma Orden, impreso en Valladolid: por Francisco Fernández de Córdoba: véndese en casa de Antonio Coello y a su costa, 1612. Juan López, Tercera parte de la Historia general de Santo Domingo y de su Orden de Predicadores, por Juan López, obispo de Monopoli de la misma Orden, en Valladolid: por Francisco Fernández de Córdoba y a su costa, 1613.

57. Hernando del Castillo, Primera parte de la Historia general de Santo Domingo, y de su Orden de Predicadores por el Maestro Fray Hernando de Castillo, impresa en Valencia: en casa de Pedro Patricio Mey a costa de Balthasar Simon, 1587; Juan López, Cuarta parte de la historia general de Santo Domingo y de la orden de Predicadores, Valladolid: Francisco Fernández de Córdoba, 1615.

58. Probable referencia a la Historia general del mundo del tiempo del rey Felipe II, desde 1559 hasta su muerte, Madrid, 1601-1612.

59. Fray Jerónimo Román, Repúblicas del mundo divididas en XXVII libros, Medina del Campo: Francisco del Canto, 1575.

60. Esteban de Garibay y Zamalloa, Compendio historial de las crónicas y universal historia de todos los reinos de España, Amberes: Cristóbal Plantino, 1571.

61. Valerio Reginaldo, Compendiaria praxis difficiliorum casuum conscientiae in tres partes [...] auctore R. P. Valerio Reginaldo e Societate Iesu, Moguntiae: sumptib. Petri Henningij Bibliop. Colon. Excudebat Ioannes Volmari, 1619.

62. Martín de Roa, Málaga. Su fundación, su antigüedad eclesiástica y seglar, en Málaga: por Juan Rene, 1622.

63. Jacques Saliano de Aviñón, Annales ecclesistici veteris testamenti in quibus res gestar ab orbe condito ad Christi navitatem et mortem per annos fere singulos digeruntur, auctore Jacobo Saliano Avenionensi Societatus Jesu presbitero, Lutetia Parisiorum: ex officina Nivelliana, sumptibus Sebastian Cramoisy [...], 1619.

64. Seguir el criterio de los jesuitas a la hora de comprar libros no le impide hacer prueba de una gran libertad de conciencia cuando condena explícitamente el apoyo de los jesuitas al padre Román de la Higuera. El abad de Rute no duda en ningún momento del carácter apócrifo de los textos que pretendió descubrir: «Los padres de la Compañía, porque el padre Higuera sacó a luz a Dextro, le defienden [...] pero no sé yo para qué hombres doctos quieren valerse de autor de fe dudosa, donde sobra tantos de cierta» (Carta n. ${ }^{\circ} 41$, Rute, 7 de julio de 1625).

65. En varias cartas el abad de Rute dice que el señor Andrés tiene «pan» suyo (es decir cereales) y da órdenes para venderlo o no, según los precios del mercado (Carta n. ${ }^{\circ} 43$, Rute, 8 de septiembre, 1625).

66. Egidio de Coninck, Commentariorum ac disputationum in uniuersam doctrinam D. Thomae de Sacramentis et censuris tomi duo auctore Ægidio de Coninck [...] è Soc. Iesu, Antuerpiae: apud haeredes Martini Nuti, 1619.

67. Por ejemplo escribe: «Los libros ya vuestra merced sabe han de darse al licenciado Castillo» (Carta.$^{\circ} 27$, Rute, 24 de septiembre de 1624).

68. «Libro de mano» significa manuscrito.

69. Carta n. ${ }^{\circ} 14$, Rute, 1 de octubre de 1622.

70. Disanto: día de fiesta religiosa. Se usa de manera irónica para designar un día temido.

71. Lorenzo Ramírez de Prado, Typographus lectori, Madrid: por Alonso Martín, 1612.

72. La carda es una especie de embarcación semejante a la galeota (RAE). «Los que estamos en el mismo barco». 
73. Carta $n .{ }^{\circ}$ 39, Rute, 16 de junio, 1625 : «Si vuestra merced le diera gusto a su padre [Dios] en ordenarse, como tantas veces le he rogado a vuestra merced, él le acudiera en ésta y otras ocasiones; y a un clérigo, aunque sea de misas, no le falta. Hágalo vuestra merced y créame». El abad de Rute parece hablar a partir de su experiencia propia.

\section{RESÚMENES}

A partir del análisis y de la edición actualmente en curso de las cartas eruditas de don Francisco Fernández de Córdoba, abad de Rute, se intenta reconstruir la biblioteca de este erudito. Se utilizan el Parecer, enviado a Góngora, así como 49 cartas, inéditas hasta la fecha, dirigidas a Díaz de Rivas, otro participante de la polémica gongorina, que versan sobre cuestiones de literatura, historia y arqueología. Dichas cartas ofrecen dos fuentes de informaciones explotables: las respuestas a las preguntas de erudición planteadas por el joven Díaz de Rivas revelan qué libros estaban presentes en la biblioteca de don Francisco, que vivía a la sazón en la pequeña ciudad de Rute; por otra parte, los pedidos de libros incluidos en las mismas cartas revelan qué adquisiciones hizo el abad de Rute a través de su joven amigo en el periodo de 1620-1626.

Starting from the analysis and ongoing edition of the scholarly letters of Don Francisco Fernández de Córdoba, abbot of Rute, this paper is an attempt to piece back together the library of that scholar. The material that has been used includes the Parecer, sent to Góngora, as well as the 49 hitherto unpublished letters to Pedro Díaz de Rivas, who also took part in the gongorine controversy, about literary, historical and archeological matters. Those letters provide two very useful sources of information: the answers to the erudite questions asked by Díaz de Rivas reveal which books were indeed in the library of don Francisco, who then lived in the small town of Rute; besides, the book-orders placed in those letters tell us which books the abbot of Rute acquired through his young friend over the $1620-1626$ period.

À partir de l'analyse et de l'édition actuellement en cours des lettres érudites de don Francisco Fernández de Córdoba, abbé de Rute, on tente ici de reconstruire la bibliothèque de cet érudit. Sont utilisés le Parecer, envoyé à Góngora, ainsi que les 49 lettres, jusqu'alors inédites, adressées à Díaz de Rivas, un autre participant de la polémique gongorine, qui portent sur des questions de littérature, d'histoire et d'archéologie. Ces lettres offrent deux sources d'informations exploitables : les réponses aux questions d'érudition posées par le jeune Díaz de Rivas révèlent les livres présents dans la bibliothèque de don Francisco, qui vivait alors dans la petite ville de Rute; par ailleurs, les commandes de livres incluses dans les mêmes lettres montrent quelles acquisitions l'abbé de Rute fit à travers son jeune ami dans la période de 1620-1626. 


\section{ÍNDICE}

Mots-clés: Francisco Fernández de Córdoba, abbé de Rute, Pedro Díaz de Rivas, Luis de Góngora, bibliothèque, érudition, circulation des livres

Palabras claves: Francisco Fernández de Córdoba, abad de Rute, Pedro Díaz de Rivas, Luis de Góngora, biblioteca, erudición, circulación de los libros

Keywords: Francisco Fernández de Córdoba, abbot of Rute, Pedro Díaz de Rivas, Luis de Góngora, library, erudition, scholarship, circulation of books

\section{AUTOR}

\section{MURIEL ELVIRA}

Université Grenoble Alpes, ILCEA4 